\title{
Újdonságok a nefro-diabetológiában
}

\author{
Wittmann István dr.
}

\begin{abstract}
Összefoglalás
Az elmúlt évek érdekes és fontos fejleményei miatt újra a diabeteses vesekárosodásra terelödött a figyelem. A betegek ellátása érdekében rutinszerüen kell tudni alkalmazni ugyanis a krónikus vesebetegséggel és a maradéknephron-hiperfiltrációval kapcsolatos ismereteket. Ez utóbbi alapján vált érthetövé, miért nem szabad törekedni a maradék GFR növelésére. A diabeteses vesebetegség esetén a tubulointerstitialis károsodások legalább olyan fontosak, mint az említett glomerularis elváltozás. Érdemes különleges figyelmet szentelni a diabeteses vesebetegek tubulointerstitialis károsodásából adódó normocytear, normokróm anaemiájának, amely prognosztikus faktora a diabeteses vesebetegségnek. Idős cukorbetegekben az eGFR-csökkenés, már a 60-90 ml/perc/1,73 m² közötti tartományban is, jelentöséggel bír a CVD-szövödmények kockázatának növekedése miatt. A RAAS-gátlókkal és az SGLT-2-gátlókkal történö kezelés kezdeti és átmeneti eGFR-csökkenést vált ki, ami a maradék nephronok hiperfiltráció-csökkenését jelzi, és igy vezet a tartósan stabil eGFR-hez. Továbbá, a RAAS és az SGLT-2-enzim gátlása albuminuria-és proteinuria-csökkentö is. Igy ismét bövült a diabeteses vesekárosodás kezelési lehetösége az SGLT-2-gátló empagliflozinnal és dapagliflozinnal, illetve az inkretin-természetü liraglutiddal.

- Kulcsszavak: becsült GFR, diabeteses vesebetegség, kóros albuminuria, maradéknephron-hiperfiltráció, tubulointerstitialis károsodás
\end{abstract}

\section{An up-date in the nephro-diabetology}

Summary: Diabetic kidney damage was brought into the focus again due to the interesting and important developments of the knowledge in the last years. One has to be able to use routinely this knowledge related to the chronic kidney disease and to the single-nephron hyperfiltration. This last phenomenon explained why the increase of remaining glomerular filtration rate should not be a goal of the therapy. Tubulointerstitial damages in diabetic kidney disease are at least as important as that of glomerular abnormalities. It is worthwhile to pay an attention to the normocytic, normochromic anaemia due to the tubulointerstitial damage of diabetic kidney patients, which anaemia is a prognostic predictor of this disease. In diabetic patients the decrease of estimated GFR (eGFR) already in the range of $60-90 \mathrm{ml} / \mathrm{min} / 1.73 \mathrm{~m}^{2} l$ leads to the increase of the risk of cardiovascular diseases, even in old patients. Using inhibitors of renin angiotensin aldosterone system (RAAS) and sodium glucose cotransporter-2 (SGLT-2), an early drop of eGFR could be detected which is due to the decrease of the single-nephron hyperfiltration and this leads to a long term stabilization of the kidney function. Inhibition of RAAS and SGLT-2 causes a decrease of albumin- and proteinuria, as well. Thus, diabetologists have some new management possibilities in the therapy of diabetic kidney disease using the SGLT-2 inhibitor empagliflozine and dapagliflozine, moreover we have also an incretin, the liraglutide for this goal.

- Keywords: abnormal albuminuria, diabetic kidney disease, estimated GFR, single-nephron hyperfiltration, tubulointerstitial damage.

DIABETOLOGIA HUNGARICA 25 (№3) 195-203. 2017. április DOI: $10.24121 / \mathrm{dh} .2017 .15$

$\mathrm{A}$ 2-es típusú cukorbetegség kezelésének utóbbi években bekövetkezett robbanásszerű fejlődése lehetővé tette a diabeteses szövődmények kockázatának csökkentését is. Az új terápiás eljárások birtokában ma már való- ban személyre szabott kezelést folytatunk. Ezek az új szerek egyben rávilágítanak a cukorbetegség eddig kevésbé előtérben álló, de mégis fontos tulajdonságaira is, mint például a vesének a szénhidrát-háztartásban játszott szerepére. 
Új adatokkal rendelkezünk mind az 1-es, mind pedig a 2-es típusú cukorbetegség hazai incidenciájáról és prevalenciájáról. ${ }^{1}$ Ezekből azt látjuk, hogy a 2-es típusú cukorbetegség incidenciája csökken, prevalenciája stagnál. A finanszírozási eredmények alapján úgy tűnik, hogy az antidiabetikumok költségének részaránya növekszik, miközben a betegenkénti összes ráfordítás változatlan, ami arra utal, hogy az utóbbi időben a szövődményekre fordított kiadás aránya csökkent. Tehát ezek alapján is feltehető, hogy az új antidiabetikumok hatékonyabbak a szövődmények megelőzésében. Az új antidiabetikumok egy része semleges a vese szempontjából (pl. dipeptidilpeptidáz-4-gátlók), egy része kedvezően befolyásolja a diabeteses veseszövődményt (pl. a liraglutid), egy része pedig éppen a vesében fejti ki a hatását és egyszerre csökkenti is a veseszövődmény kockázatát (pl. a nátrium-glukóz-kotranszporter-gátlók).

Ezek az új fejlemények arra ösztönzik a nefrológusokat és diabetológusokat, hogy az eddigieknél szorosabban együttműködjenek, illetve hogy a határterületi kérdéseket kölcsönösen megismerjék. Ezt igyekszik szolgálni a jelen öszszefoglaló is.

\section{1. táblázat. A GFR-kategóriák}

\begin{tabular}{|c|c|c|}
\hline GFR kategória & $\begin{array}{c}\text { GFR } \\
\left(\mathrm{ml} / \text { perc/1,73 } \mathrm{m}^{2}\right)\end{array}$ & Leírás \\
\hline G1 & $\geq 90$ & Normális vagy magas \\
\hline G2 & $60-89$ & Enyhén csökkent \\
\hline G3a & $45-59$ & $\begin{array}{l}\text { Enyhén, mérsékelten } \\
\text { csökkent }\end{array}$ \\
\hline G3b & $30-44$ & $\begin{array}{c}\text { Mérsékelten, súlyosan } \\
\text { csökkent }\end{array}$ \\
\hline G4 & $15-29$ & Súlyosan csökkent \\
\hline G5 & $<15$ & Veseelégtelenség \\
\hline
\end{tabular}

\section{Változások a vesebetegségek osztályozásában}

A korábbi „veseelégtelenség” terminológia helyett az utóbbi években a krónikus vesebetegség szót használjuk és az angol elnevezés alapján (chronic kidney disease) a CKD rövidítést alkalmazzuk. ${ }^{2}$ Ennek az az értelme, hogy az idült vesebetegség nem feltétlenül jár a működés elégtelenségével. CKD-ról akkor beszélünk, ha a vesebetegség három hónapnál régebb óta áll fenn és az alábbiak közül legalább egy tényező megtalálható:

1. A glomerulus filtrációs ráta (GFR) kóros volta (1. táblázat)

2. Kóros albuminuria (2. táblázat)

3. Kóros vizeletüledék

4. Kóros ionok

5. Kóros hisztológia

6. Kóros képalkotólelet

7. Vesetranszplantáció az anamnézisben

A GFR kóros értékéről a $<90 \mathrm{ml} /$ perc/1,73 m² és a $>125 \mathrm{ml} /$ perc/1,73 $\mathrm{m}^{2}$ esetén beszélünk. Az előző esetben vesefunkció-beszűkülést, az utóbbi esetben hiperfiltrációt említünk. Az utóbbi időben számos vitát váltott ki a $60-90 \mathrm{ml} /$ perc/1,73 $\mathrm{m}^{2}$ közötti GFR-adatok értékelése. Ehhez ismernünk kell azt is, hogyan jutunk a GFR értékének birtokába. Már régóta nem javasoljuk az endogén kreatinin clearance meghatározását annak nehézkessége és pontatlansága miatt, hanem helyette a becsült GFR (az angol elnevezés alapján estimated GFR, eGFR) használata terjedt el.

\section{Az eGFR használata: a vesefunkció beszükülése}

Az eGFR kiszámításához korábban használt Cockroft-Gault-egyenlet elavult (bár az USA-ban még mindig alkalmazzák és a gyógyszer-előira-

\section{2. táblázat. Az albuminuria-kategóriák}

\begin{tabular}{|c|c|c|c|}
\hline Albuminuria-kategória & $\begin{array}{c}\text { Napi albuminürítés } \\
\text { (mg/24 óra) }\end{array}$ & $\begin{array}{c}\text { Albumin-kreatinin hányados } \\
\text { (mg/mmol) }\end{array}$ & Leirás \\
\hline A1 & $<30$ & $<3$ & Normális \\
\hline A2 & $30-300$ & $3-30$ & Súrsékelten emesanemelkedett \\
\hline A3 & $>300$ & $>30$ & emedt \\
\hline
\end{tabular}


tokban szereplő eGFR szinte kizárólag ennek a képletnek a kiszámolásával került meghatározásra), és az utána évekig alkalmazott MDRD képlet szintén kikerült a rutinból, mivel ez csak $<60$ $\mathrm{ml} / \mathrm{perc} / 1,73 \mathrm{~m}^{2}$ esetén volt megbízható. Valószínűleg ennek maradványaképpen szerepel még mindig az ajánlásokban, hogy csak eGFR <60 $\mathrm{ml} /$ perc/1,73 $\mathrm{m}^{2}$ esetén állapíthatjuk meg a kórosan beszűkült eGFR-t.

A másik kifogás a 60-90 ml/perc/1,73 m² közötti eGFR-adatok kórosnak történő elfogadása ellen általában az, hogy ez nem más, mint az ún. fiziológiás GFR-vesztés időskorban. Azonban ismert olyan régebbi ${ }^{3}$ és újabb ${ }^{4}$ klinikai eredmény is, az előbbi 73,4 éves, harmadrészt diabetesesekben, az utóbbi 65 év feletti 2-es típusú cukorbetegekben, amelyek azt bizonyítják, hogy az idősek között az eGFR-vesztés jelentős kockázati tényezője a myocardialis infarktusnak, a cardiovascularis betegségnek (CVD), a major cardiovascularis eseménynek (MACE), sőt az összmortalitásnak is. A korábbi közlemény igazolta, hogy - küszöbérték nélkül $10 \mathrm{ml} /$ perc/1,73 m² eGFR-csökkenés szignifikánsan, 5\%-kal növeli a CVD és 6\%-kal az összmortalitás kockázatát. Így ez a $60-90 \mathrm{ml} /$ perc/1,73 m² közötti GFR-csökkenést nem lehet fiziológiásnak nevezni, orvosi kezelést igényel, hiszen kialakulásának kockázata csökkenthető, részben az új antidiabetikumokkal, másrészt a renin-angiotenzin-aldoszteron rendszert (RAAS) gátló gyógyszerekkel (lásd később).

\section{Az eGFR használata: a hiperfiltráció}

Új fejlemény az is, hogy a jelenleg az eGFR számolására használt CKD-EPI képlet alkalmas lehet a hiperfiltráció becslésére is, bár a rutinban egyelőre ez nem kerül megadásra. Amennyiben klinikai tanulmányokkal is igazolható a hiperfiltráció kezelésének haszna (pl. nátrium-glukóz-kotranszporter-2, SGLT-2-gátlóval, lásd később), érdemes lesz erre figyelnünk.

A hiperfiltrációt kimutatták mind 1-es, mind 2-es típusú cukorbetegségben. ${ }^{5}$ Korábban, az 1980-as évek végétől a 2010-es évek elejéig, elsősorban izotóp- vagy inulin-clearance-et használtak, és csak az utóbbi években kezdték el alkalmazni az eGFR-t a hiperfiltráció igazolására. Az alkalmazott küszöb-GFR-érték is különbözött, általában 120-140 ml/perc/1,73 m² közé esett és ezeknek a köszöbértékeknek a használatával a hiperfiltráció előfordulása 1-es típusú cukorbetegekben (12 tanulmány alapján) 10-67\%, 2-es típusúakban (17 tanulmány alapján) 6-58\% közöttinek adódott.

A hiperfiltrációt felfoghatjuk úgy is, hogy a vese rezervkapacitása jelenik meg ilyenkor, ami a vese károsodásának előrehaladása során elvész. Még normálisnak látszó globális GFR-érték esetén már jelentős nephronpusztulás lehet, amit a maradék nephronok hiperfiltrációja kompenzál (1. ábra).

\section{A maradéknephron-hiperfiltráció jelentösége}

Ez a maradéknephron-hiperfiltráció a kulcsa a további események és a terápiás lehetőségek megértésének (1. ábra). Ahogy az egész vesére nehezedő, globális hiperfiltráció károsítja a sérülékenyebb nephronokat (valószínűleg ebben kulcsszerepet játszik a sejtek nyújtása, feszülése ${ }^{6}$ ), úgy a nephronok jelentős számának pusztulása után a maradék nephronok hiperfiltrációja károsítja a

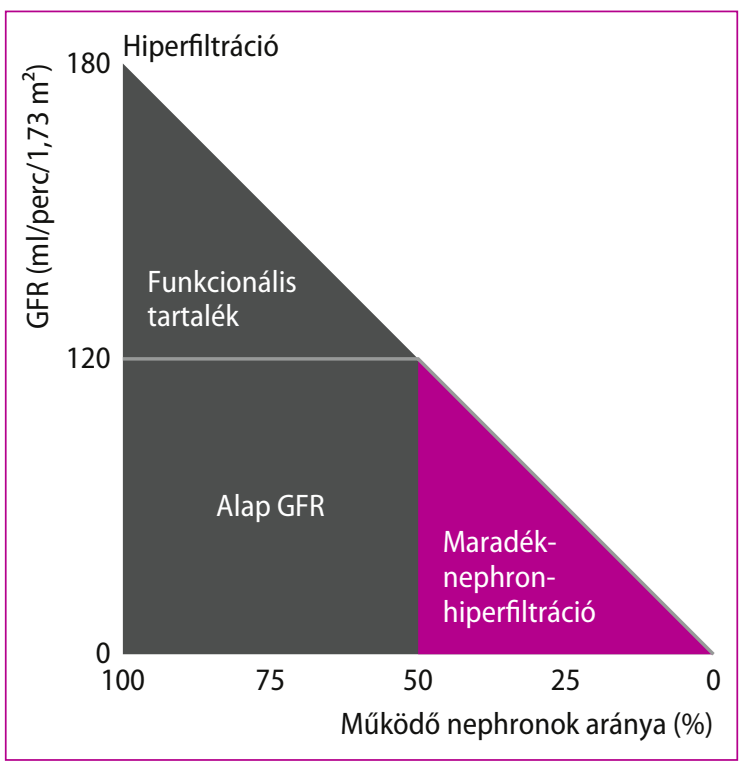

1. ábra. A vese müködési kapacitása és a maradéknephron-hiperfiltráció (Tonneijck L és mtsai alapján módositva ${ }^{5}$ ) 
maradék nephronokat. Leírója után ezt az ördögi kört Brenner-hipotézisként emlegetik, ${ }^{7}$ és ennek a megszakítása a vesevédelem célja.

Ilyenkor már hiába próbáljuk növelni a GFR-t, ezt csak a maradéknephron-hiperfiltráció emelése árán tudjuk megtenni, ami csak gyorsítja a nephronpusztulást. Ezt eredményezte pl. az antioxidáns kezelés bardoxolon metillel, ${ }^{8}$ vagy saját vizsgálatainkban rezveratrollal, ${ }^{9}$ amelyek ugyan emelték a károsodott veséjü betegek eGFR-jét, de ezzel parallel növelték a proteinuriát, ami a glomerularis és tubularis károsodás rosszabbodásának markere.

A teendő ilyenkor, a maradéknephron-hiperfiltráció esetén nem lehet más, mint a maradéknephron-hiperfiltráció csökkentése. A maradéknephron-hiperfiltrációt két tényező okozhatja, a glomerulus afferens arteriolájának dilatációja és az efferens arteriola konstrikciója.

\section{A hiperfiltráció befolyásolása: az afferens arteriola vasodilatatiójának csökkentése}

$\mathrm{Az}$ afferens arteriola dilatációját befolyásoló tényező többek között a hyperinsulinaemia vazodilatátor hatása vagy a tubuloglomerularis feed-back (TGF) folyamata. A 2-es típusú cukorbetegekben, az inzulinrezisztencia miatt, az inzulin nitrogén-monoxidon keresztül megvalósuló vasodilatatiós hatása csökken, ezért inkább a TGF jelentőségével kell számolnunk. A TGF aktiválása létrejöhet a macula densa sejtekhez érkező csökkent vizeletnátrium-koncentráció miatt, aminek hátterében, a 2-es típusú cukorbetegségben, a vesében fokozottan termelődő aldoszteron állhat, amely növeli a nátrium-reabszorpciót. Ilyenkor a TGF révén arteriola afferens vasodilatatio alakul ki. Azok a hatások, amelyek növelik a vizelet nátriumtartalmát, azok csökkentik a TGF révén az arteriola afferens vasodilatatióját. Ilyenek lehetnek az SGLT-2 enzim gátlói.

\section{A hiperfiltráció befolyásolása: az efferens arteriola vasoconstrictiójának csökkentése}

$\mathrm{Az}$ efferens arteriola vasoconstrictiójáért elsősorban az angiotenzin II lehet a felelős, ezért a RAAS gátlói csökkentik a maradéknephron-hiper- filtrációt. Előrehaladott vesekárosodásban (GFR $<45 \mathrm{ml} /$ perc/1,73 $\mathrm{m}^{2}$ ) történő elkezdésük ellenjavallt, mert az arteriola efferens tágítása révén olyan glomerularis nyomáseséshez vezethet, amely leállíthatja a filtrációt, ami viszont nem jelenti azt, hogy a már korábban (magasabb GFR mellett) elkezdett RAAS-gátló kezelést abba kellene hagyni a GFR ilyen mértékű csökkenésekor.

\section{A korai GFR-csökkenés SGLT-2- vagy RAAS-gátló kezelés megkezdésekor mint kedvezö jel}

Amikor RAAS-gátló kezelést indítunk, pl. angiotenzinreceptor-blokkolóval $\left(\operatorname{losartan}^{5}\right)$, minél nagyobb a kezelés megkezdésekor tapasztalt GFR-esés, annál valószínűbb a hosszú távú stabilizálódása a GFR-nek. Világosan ki kell zárni azonban azokat a betegeket, akiknek több mint 30\%ot esik a GFR-jük a RAAS-gátló elkezdésekor, mert ilyenkor ischaemiás nephropathia valószínű, melynek hátterében renalis artériaszükület állhat, és ilyenkor azonnal le kell állítani a RAAS-gátlót és részletes kivizsgálást kell végezni.

A RAAS-gátló kezeléshez hasonlóan az SGLT2-inhibitorok elkezdésekor gyors GFR-esést észlelünk, amely a fent részletezett módon jöhet létre, és amelyet a RAAS-gátlóknál látottaknak megfelelően jó jelként kell felfognunk, ami mutatja a maradéknephron-hiperfiltráció csökkenését és hosszú távon valószínűsíti a GFR stabilizálódását.

Kérdéses, hogy a már RAAS-gátló kezelésen lévő betegek esetében elkezdett SGLT-2-inhibitor terápia additív vesevédő hatású, vagy kisebb, esetleg potencírozó vesevédelmet eredményez. Az eddigi vizsgálatok nagyrészt RAAS-gátlásban történő SGLT-2-kezelést alkalmaztak jó eredménnyel, de ezt a problémát direkt módon vizsgáló klinika tanulmány nem áll rendelkezésünkre.

\section{A CKD előfordulása cukorbetegségben}

Az USA-ban készült egyik felmérés (1999-2006, National Health and Nutrition Examination Survey, NHANES) azt vizsgálta, hogy milyen a CKD előfordulása a prediabeteses, az ismert diabeteses 
és a frissen felfedezett diabeteses betegek, illetve a nem cukorbetegek között. ${ }^{10}$

A CKD definíciója a következő volt: CKD1: eGFR $>90 \mathrm{ml} /$ perc/1,73 $\mathrm{m}^{2}$ és kóros albuminuria; CKD2: eGFR 60-89 ml/perc/1,73 $\mathrm{m}^{2}$ és kóros albuminuria; CKD3 és 4: eGFR 15-59 ml/perc/1,73 $\mathrm{m}^{2}$. Az albuminürítést csak egyszer határozták meg, és nem 3 független vizsgálat eredményén alapult, ahogy az az ajánlásokban szerepel. A résztvevők $(n=8188) 20$ évnél idősebbek voltak, a szérumkreatinin-értékeket korrigálták és a CKD-EPI egyenletet használták.

A betegcsoportokat a következőképpen definiálták a szénhidrát-anyagcsere szempontjából: ismert diabetes, a beteg által bejelentett diagnózis $(n=826)$; frissen felfedezett diabetes: a beteg nem tudott cukorbetegségről, de a vizsgálat során az éhomi plazmaglukóz magasabb volt, mint $7,0 \mathrm{mmol} / \mathrm{l}(\mathrm{n}=299)$; prediabetes: az éhomi plazmaglukóz 5,6-7,0 mmol/l közöttinek bizonyult $(\mathrm{n}=2272)$, és szénhidrátanyagcsere-egészséges, akinek éhomi plazmaglukózértéke alacsonyabb volt, mint 5,6 mmol/l $(\mathrm{n}=4791)$.

A CKD korrigálatlan előfordulása szénhidrát-anyagcsere szempontjából egészségesek között $9,2 \%$, prediabetesben $16,6 \%$, frissen felismert diabetesben $40,0 \%$ és ismert diabetesben $38,5 \%$ volt.

Kíváncsiak voltunk arra, hogyan alakul a CKD előfordulása saját, nem reprezentatív, fekvőbeteg-ellátásunkban, ezért a 2015-2016 éves adatainkat feldolgoztuk. Zárójelentéseink diagnózisait és a laboratóriumi eGFR-eredményeket szűrtük. Az adott időszakban 1268 betegünk zárójelentésének diagnózisai között szerepelt a „diabetes mellitus” és „2-es típus” megjelölés egyszerre. A kóros albuminuriát nem kerestük a dokumentációnkban, kizárólag a CKD-EPI egyenlet alapján válogattuk szét ezt az 1268 beteget. A százalékos előfordulás a következőképpen alakult:

- eGFR >90 ml/perc/1,73 $\mathrm{m}^{2}: 3,64 \%$,

- eGFR $60-89 \mathrm{ml} / \mathrm{perc} / 1,73 \mathrm{~m}^{2}: 46,76 \%$,

- eGFR 30-59 ml/perc/1,73 m²: 31,09\%,

- eGFR 15-29 ml/perc/1,73 m²: 9,65\%,

- eGFR < $15 \mathrm{ml} /$ perc/1,73 $\mathrm{m}^{2}: 8,86 \%$.

A fentiekben részletezett, a vesefunkció beszüküléséről írottak fényében elgondolkodtatók ezek az eredmények, még akkor is, ha tudjuk, hogy klinikánk III. progresszivitási szintű ellátóhelye a diabeteses vesekárosodásnak.

\section{Cukorbetegek CKD-ja kóros albuminürítéssel}

Az utóbbi évtizedben általánossá vált a proteinuriás vagy kóros albuminuriás cukorbetegek RAASgátló kezelése. A fentiekben részletezett módon ez csökkenti a proteinurát és az albuminuriát. Tovább javult a helyzet azoknak az antidiabetikumoknak a használatával, amelyek szintén proteinuria- és albuminuriacsökkentők. Ilyen pl. a pioglitazon, az SGLT-2-gálók, a liraglutid. A nemzetközi ajánlásokból tudjuk, hogy a proteinuria, albuminuria csökkentése a vesebetegség progressziójának lassítását jelenti. ${ }^{2}$ Ugyanezek az ajánlások arra is felhívják a figyelmet, hogy a proteinuria csökkentése egyszersmind a CVD kockázatát is mérsékli.

$\mathrm{Az}$ összefüggés a diabetes, a proteinuria (albuminuria), a CKD és a CVD között a következőképpen magyarázható: A diabetes egyszerre károsítja a vesét és a vesén kívüli ereket. Igy ezek (a CKD és a CVD) együtt progrediálnak, aminek vese-megnyilvánulása a proteinuria (kóros albuminuria) és a GFR-vesztés, szív-manifesztációja az ischaemia és a szivelégtelenség. Ebben az esetben nem lehet sem reno-cardialis, sem cardio-renalis szindrómáról beszélni, amennyiben az elnevezést úgy értelmezzük, hogy az első tag a kiváltó tényezője a másodiknak, hiszen a közös kiváltó ok a cukorbetegség.

\section{Cukorbetegek CKD-ja normális albuminürítéssel}

Az általánosan alkalmazott RAAS-gátlás és a mind szélesebb körben használt antiproteinuriás antidiabetikus kezelés azt eredményezi, hogy az igazolt, gyakran szövettanilag is verifikált CKD-s cukorbetegek nem proteinuriásak, sőt még csak kóros albuminürítésük sincs. Feltételezhető, hogy ezeknek a betegeknek lassabb a GFR-vesztése. A nem proteinuriás, normoalbuminuriás cukorbetegek GFRvesztésének befolyásolása további vizsgálatok tárgya és a diabeteses vesebetegek jövőjének nagy kérdése.

\section{Vesebetegség cukorbetegségben: a tubulointerstitialis megközelítés}

Eddig döntően a vese glomerulusában zajló diabeteses elváltozások kerültek taglalásra. Ismert 
azonban, hogy a vesebetegség progressziójának legalább annyira (ha nem jobban) meghatározó tényezője a nephron tubulointerstitialis részének károsodása.

A proximális tubularis epithelsejtek reabszorbeálják a primer szűrletbe kerülő glukóz és fehérje nagy részét. Ráadásul ezek a sejtek felelősek a veséből történő glukózkiáramlás létrehozásáért, amely nagyrészt az itt zajló glukoneogenezisből származik. Ennek részvételi aránya az összes sejtből történő glukózkiáramlás (ebbe beleértendő a hepatikus glukózkiáramlás is) $20-25 \%$-át is elérheti.

Az által, hogy a proximális tubularis epithelsejtek reabszorbeálják a filtrált glukóz nagy részét, hyperglykaemia esetén ezek a sejtek hatalmas glukotoxicitásnak vannak kitéve. Ez a glukotoxicitás azt jelenti - mint minden sejt esetében -, hogy intracelluláris oxidatív stressz jön létre. Ez a sejtek nekrózisát vagy apoptózisát hozza magával, de a pusztulásukig számos, a környezetüket is érintő káros folyamat elindulását is okozzák. Így pl. az oxidatív stressz hatására az epithelsejtekben a Nf- $x$ B transzlokálódik a sejtmagba, ahol megindítja a citokinek, gyulladásos és profibrotikus faktorok termelődést. Ezek károsítják a peritubularis sejteket, a kapillárisokat (ez hipoxiához vezet) és a tubulointerstitialis fibroblasztokat, amelyek az eritropoetin termeléséért felelősek. Ezért a diabeteses vesekárosodás ún. „korai” anaemiához vezet. Azt értjük kora anaemia alatt, hogy a GFR viszonylag enyhe beszűkülése esetén is már kialakul a veseeredetű (normocytaer, normokróm) anaemia. Számos klinikai tanulmányban igazolták, hogy a cukorbetegekre nemcsak a „korai” anaemia jellemző CKD-ban, hanem az anaemia korrelál az inzulinrezisztenciával is. Az a klinikai vizsgálat, amely igazolta, hogy az anaemiát kivéve minden szempontból azonos kiindulási értékekkel rendelkező 2-es típusú cukorbetegek esetében a 10 éves követés során a kiinduláskor anaemiásak között sokkal gyakoribb a vesepótló-kezelési igény, hangsúlyozza a tubulointerstitialis károsodás jelentőségét a cukorbetegség okozta vesekárosodás kifejlődésében. ${ }^{11}$

Itt szükséges megjegyezni azt is, hogy nagyrészt az inzulinrezisztencia a felelős a kóros albuminuria korai fázisának (nyilvánvalóan nem a podocyta-leválásos forma) kifejlődéséért is. A proximális tubularis epithelsejtek (PTE) korai glukotoxikus károsodása ezekben a sejtekben inzulinrezisztencia kialakulásához vezet (nem igaz tehát az a magát még mindig tartó elképzelés, hogy a vese

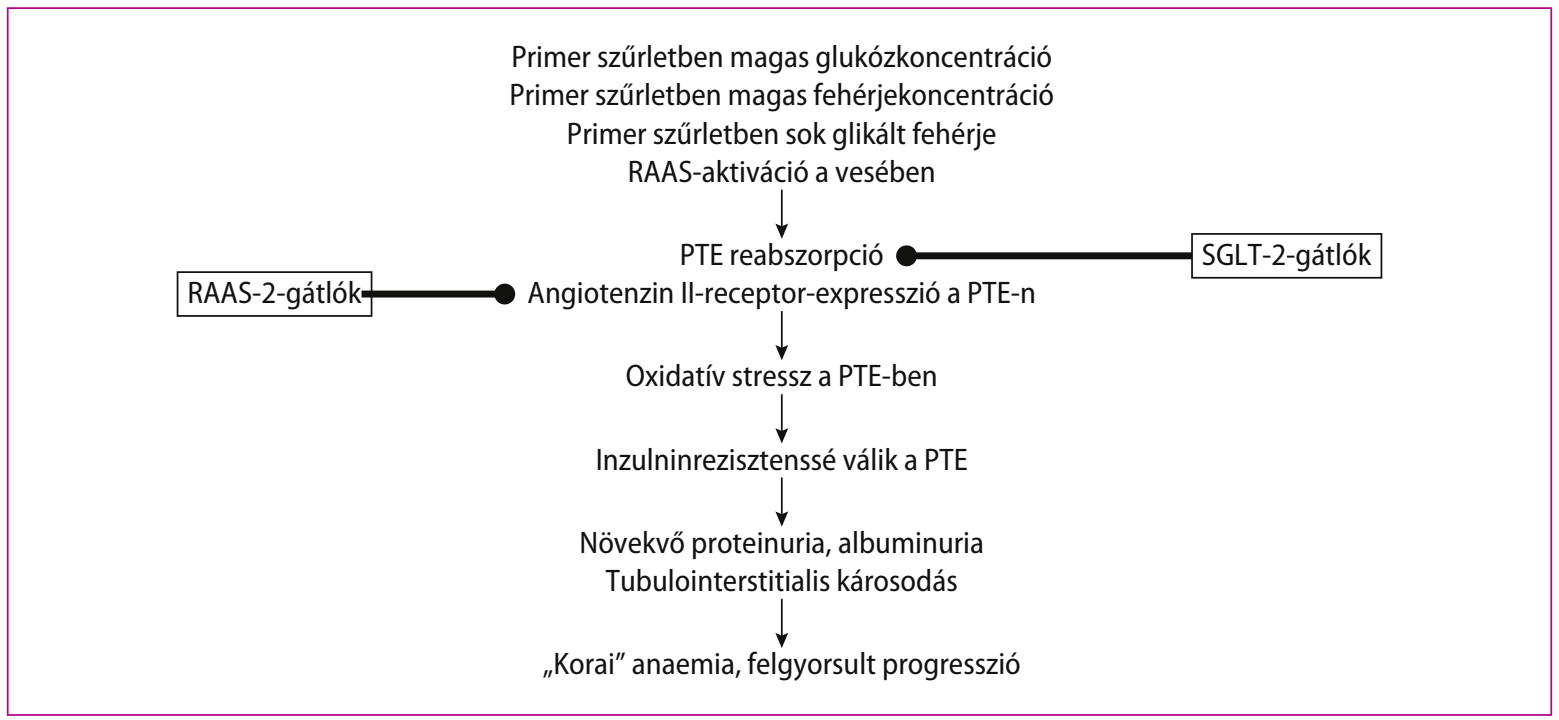

2. ábra. A hyperglykaemia, a proteinuria, a nem enzimatikus glikáció, a renin-angiotenzin-aldoszteron rendszer (RAAS), a RAAS-gátlók és a nátrium-glukóz-kotranszporter-2 (SGLT-2)-gátlók szerepe a proximális tubularis epithelialis (PTE) sejtek károsodásának, a vesebetegség progressziójának kialakulásában és annak kivédésében 
nem válik inzulinrezisztenssé 2-es típusú cukorbetegségben). Mivel az albumin reabszorpciójáért a PTE tubularis lumen felé néző felszínén található megalin-kubilin interakciója szükséges, a keletkező heterodimer szolgál az albumin receptoraként, és ezt a megalin-kubilin interakciót az inzulin indítja meg, inzulinrezisztenciában elégtelen az albumin-visszaszívás.12 Ezért minden olyan kezelés, amely csökkenti a PTE glukotoxicitását (SGLT-2gátlók) vagy direkt módon ezek inzulinrezisztenciáját (pioglitazon), albuminuria-csökkentő hatású.

Érdekes megfigyelés szerint a PTE-ben kifejlödő glukotoxicitás csökkenthető az ezeknek a sejteknek a felszínén lévő angiotenzin II 1-es típusú receptor kifejeződésének csökkentésével (ún. „silencing" kismolekulasúlyú RNS-sel, small interfering RNA, siRNA). ${ }^{13} \mathrm{Ez}$ a rutin betegellátásban is megvalósítható, de nem a „silencing” révén, hanem a filtrálódó és az epithelsejteket így elérő angiotenzinreceptor-blokkoló (ARB) vagy angiotenzinkonvertáló enzim gátló (ACEI) segítségével.

Fontos megjegyezni, hogy a reabszorbeált albumin is toxikus a PTE-re, különösen cukorbetegségben, amikor az albumin még glikált is,${ }^{14}$ amely az epithelsejtben oxidatív stresszt kelt, amit az ARB csökkent, így javítva az epithelsejt inzulinérzékenységét, ami indirekt módon növeli a fehérje-reabszorpciót a már említett módon, a megalin-kubilin úton. Ezek alapján tehát a RAASgátlók nemcsak a glomerulusban fejtenek ki kedvező (hemodinamikai) hatást, hanem direkt tubularis epithelsejt védők is.

Összefoglalva, nem csak a glomerularis, hanem a tubularis károsodások is fontosak a diabeteses vesebetegség kialakulásában, ezért ennek gyógyszeres befolyásolása legalább olyan hatékony, mint a glomerulus károsodásainak kezelése (2. ábra).

\section{Új kezelési lehetőségek cukorbetegség okozta vesebetegségben}

\section{Nátrium-glukóz-kotranszporter-2-gátlás}

\section{Az EMPA-REG OUTCOME vizsgálat vesekimenetele $e^{15}$}

A fent részletezettek miatt az SGLT-2-gátlók vesevédő hatásúak két támadásponton keresztül is: csökkentik a maradéknephron-hiperfiltrációt és a PTE-glukotoxicitást.

Az EMPA-REG OUTCOME tanulmány 2016 nyarán szolgáltatta az első magas szintű evidence based medicine (EBM) bizonyítékot az SGLT2-gátlás kedvező vesehatásáról. Ebben a vizsgálatban az elsődleges végpont az empagliflozin cardiovascularis hatása volt, de előre meghatározott módon a renalis végpontokat is mint másodlagos kimenetelt figyelembe vették.

A bevont betegek 2-es típusú cukorbetegek voltak, akiknek az eGFR-je nagyobb volt, mint 30 $\mathrm{ml} /$ perc $/ 1,73 \mathrm{~m}^{2}$. Az előre meghatározott kombinált vesevégpont a vesebetegség kialakulása vagy rosszabbodása volt, ami az albuminuria macroalbuminuráig való romlásából, a szérumkreatinin duplázódásból, vesepótló kezelés indításából, illetve veseeredetủ halálozásból állt. Vesevégpontként megjelölték még a microalbuminuria kialakulását is.

A kombinált vesevégpont az empagliflozin csoportban 525 betegnél jelentkezett (a teljes, empagliflozinnal kezelt populáció 4124 betegből állt), ami $12,7 \%$-ot tett ki, és az eseményráta a placebocsoportban (388 eset 2061 beteg közül) 18,8\% volt, (az empagliflozin csoport esélyhányadosa 0,61; a 95\%-os konfidenciaintervallum 0,53-0,70; $\mathrm{p}<0,001)$. További szignifikáns, vesevédő hatást tükröző eredmények: progresszió macroalbuminuriába $(0,62[0,54-0,72])$, a szérumkreatinin duplázódása, amit eGFR < $45 \mathrm{ml} /$ perc/1,73 $\mathrm{m}^{2}$ kísért $(0,56[0,39-0,79])$, vesepótló kezelés indítása $(0,45$ $[0,21-0,97])$. A microalbuminuria kialakulásának kockázata nem csökkent szignifikánsan.

Az eGFR-változásokat a 192. hétig követték, ami már elég hosszú idő volt ahhoz, hogy az eGFR hosszú távú alakulása is megítélhető legyen. Míg a placebocsoportban folyamatos eGFR-csökkenés volt megfigyelhető, addig az empagliflozinnal egy kezdeti eGFR-csökkenés után stabil, csökkenés nélküli eGFR-szint alakult ki.

\section{Vizsgálatok dapagliflozinnal}

Több kisebb klinikai tanulmány ${ }^{16,17}$ készült dapagliflozinnal, amelyek azt igazolták, hogy a dapagliflozin csökkenti mind a micro-, mind pedig a macroalbuminuriát, a hatás független volt a $\mathrm{HbA}_{1 c}$-re, a vérnyomásra, a GFR-re és a testsúlyra gyako- 
rolt hatástól. Az eGFR, az empagliflozinnál látottaknak megfelelően, először csökkent, majd stabilizálódott.

\section{Inkretinterápia}

\section{A LEADER vizsgálat vesekimenetele}

A LEADER vizsgálatot ${ }^{18}$ liraglutiddal végezték 2-es típusú cukorbetegekben, és az elsődleges célkitűzés a cardiovascularis végpontok tanulmányozása volt. A liraglutid csoportban 4668-an, a placebóban 4672 beteg került bevonásra. A vesevégpontok előre meghatározott, ún. „exploratory” végpontokként szerepeltek. A nephropathia végpont kombinált volt, tartalmazta a macroalbuminuria kialakulását, a szérumkreatinin duplázódását, az eGFR $45 \mathrm{ml} /$ perc $/ 1,73 \mathrm{~m}^{2}$ alá csökkenését, a folyamatos vesepótló kezelés szükségességét és a veseeredetű halálozást. Az eGFR-t a korábbi, az ún. MDRD egyenlet alapján becsülték.

A nephropathia végpont esélyhányadosa a liraglutid csoportban $0,78(0,67-0,92)$ volt, amely szignifikáns javulásnak bizonyult.

\section{A SUSTAIN-6 vizsgálat vesekimenetele}

A SUSTAIN-6 vizsgálatot ${ }^{19}$ szemaglutid felhasználásával, szintén 2-es típusú cukorbetegeken végezték, és a primer végpont itt is a cardiovascularis kimenetel volt. A szemaglutid csoportban 1648-an, a placebóban 1649 beteg szerepelt. A másodlagos végpontok között találhattuk a kombinált nephropathia végpontot, amelynek komponensei között a következők kerültek nevesítésre: tartósan fennálló macroalbuminuria kialakulása, a kreatinin duplázódása, eGFR $<45 \mathrm{ml} /$ perc $/ 1,73 \mathrm{~m}^{2}$ létrejötte, folyamatos vesepótló-kezelés szükségessége. A nephropathia végpont esélyhányadosa a szemaglutid csoportban $0,64(0,46-0,88)$ lett, ami jelentős kockázatcsökkenést tükröz. Hazánkban, egyelőre ez a szer még nem hozzáférhető.

\section{Következtetések}

Az utóbbi években sokat fejlődött a diabeteses vesebetegséggel kapcsolatos tudásunk. Új szempontok szerint értékeljük a hiperfiltrációt, a maradék- nephron-hiperfiltrációt. Érthetővé vált, miért nem szabad törekednünk a maradék GFR növelésére, és hogy a tubulointerstitialis károsodások legalább olyan fontosak, mint a glomerularis elváltozások. Bemutatásra került, hogy az eGFR-csökkenés, a $60-90 \mathrm{ml} /$ perc/1,73 $\mathrm{m}^{2}$ közötti tartományban a CVD-szövődmények kockázatának növekedése miatt nem elhanyagolható, még idősekben sem. A RAAS-gátlókkal és az SGLT-2-gátlókkal történő kezelés kezdeti és átmeneti eGFR-csökkenést vált ki, ami a tartósan stabil eGFR-t jelzi előre. Új kezelési lehetőség a diabeteses vesekárosodásban az SGLT-2-gátló empagliflozin és dapagliflozin, az inkretinterápia esetén pedig a liraglutid. 


\section{rrodalom}

1. Kempler P, Putz Zs, Kiss Z, Wittmann I, Abonyi-Tóth Zs, Rokszin Gy, et al:: A 2-es típusú diabetes előfordulása és költségterheinek alakulása Magyarországon 2001-2014 között - az Országos Egészségbiztositási Pénztár adatbáziselemzésének eredményei. Diabetologia Hungarica 2016; 3: 177-188.

2. KDIGO 2012 Clinical practice guideline for the evaluation and management of chronic kidney disease. Kidney Int Suppl 2013; 3(1): 1-150.

3. Manjunath G1, Tighiouart H, Coresh J, Macleod B, Salem DN, Griffith $\mathrm{JL}$, et al: Level of kidney function as a risk factor for cardiovascular outcomes in the elderly. Kidney Int 2003; 63(3): 1121-1129. doi:10.1046/j.1523-1755.2003.00838.x

4. Hsieh YT, Kuo JF, Su SL, Chen JF, Chen HC, Hsieh MC: Subnormal estimated glomerular filtration rate strongly predict incident cardiovascular events in type 2 diabetic Chinese population with normoalbuminuria. Medicine (Baltimore) 2016; 95(2): e2200. doi:10.1097/MD.0000000000002200

5. Tonneijck L, Muskiet MH, Smits MM, van Bommel EJ, Heerspink HJ, van Raalte DH, et al: Glomerular hyperfiltration in diabetes: Mechanisms, clinical significance, and treatment. J Am Soc Nephrol 2017; pii: ASN.2016060666. doi:10.1681/ASN.2016060666

6. Gudipaty SA, Lindblom J, Loftus PD, Redd MJ, Edes K, Davey CF, et al.: Mechanical stretch triggers rapid epithelial cell division through Piezo1. Nature 2017. doi:10.1038/nature21407

7. Brenner BM, Lawler EV, Mackenzie HS: The hyperfiltration theory: a paradigm shift in nephrology. Kidney Int 1996; 49(6): 1774-1777. doi:10.1038/ki.1996.265

8. de Zeeuw D, Akizawa T, Audhya P, Bakris GL, Chin M, Christ-Schmidt H, et al:: Bardoxolone methyl in type 2 diabetes and stage 4 chronic kidney disease. N Engl J Med 2013; 369(26): 2492-503. doi:10.1056/NEJMoa1306033.

9. Brasnyó P, Kovács T, Molnár GA, Sélley E, Kun Sz, Vas T, et al: Resveratrol causes gender-dependent and bardoxolone methyl-like effects in patients with IgA nephropathy: pilot study. J Nutr Food Sci 2016; 6: 442. doi:10.4172/2155-9600.1000442

10. Plantinga $L C$, Crews DC, Coresh J, Miller ER, Saran R, Yee J, Hedgeman E, et al.: Prevalence of chronic kidney disease in US adults with undiagnosed diabetes or prediabetes. Clin I Am Soc Nephrol 2010; 5(4): 673-682. doi:10.2215/CJN.07891109

11. Kim SH, Lee KA, Jin HY, Baek HS, Park TS: The relationship between anemia and the initiation of dialysis in patients with type 2 diabetic nephropathy. Diabetes Metab I 2015; 39(3): 240-246. doi:10.4093/dmj.2015.39.3.240

12. Coffey S, Costacou T, Orchard T, Erkan E: Akt links insulin signaling to albumin endocytosis in proximal tubule epithelial cells. PLOS One 2015; 10(10): e0140417. doi:10.1371/journal.pone.0140417.eCollection2015

13. Gong Q, Hou F: Silencing of angiotensin II type-1 receptor inhibits high glucose-induced epithelial-mesenchymal transition in human renal proximal tubular epithelial cells via inactivation of mTOR/p7056K signaling pathway. Biochem Biophys Res Commun 2016; 469(2): 183-188. doi:10.1016/j.bbrc.2015.11.092

14. Takao T, Horino T, Kagawa T, Matsumoto R, Inoue K, Taguchi T, et al.: Effects of angiotensin II type 1 receptor blocker on albumin-induced cell damage in human renal proximal tubular epithelial cells. Am J Nephrol 2009; 29(2): 102-108. doi:10.1159/000151294

15. Wanner C, Inzucchi SE, Lachin JM, Fitchett D, von Eynatten M, Mattheus M, et al:: Empagliflozin and progression of kidney disease in type 2 diabetes. N Engl J Med 2016; 375(4): 323-334. doi:10.1056/NEJMoa1515920

16. Heerspink HJ, Johnsson E, Gause-Nilsson I, Cain VA, Sjöström CD: Dapagliflozin reduces albuminuria in patients with diabetes and hypertension receiving renin-angiotensin blockers. Diabetes Obes Metab 2016; 18(6): 590-597. doi:10.1111/dom.12654
17. Fioretto P, Stefansson BV, Johnsson E, Cain VA: Dapagliflozin reduces albuminuria over 2 years in patients with type 2 diabetes mellitus and renal impairment. Diabetologia 2016; 59: 2036-2039. doi:10.1007/s00125-016-4017-1

18. Marso SP, Daniels GH, Brown-Frandsen K, Kristensen P, Mann JF, Nauck MA, et al.: Liraglutide and cardiovascular outcomes in type 2 diabetes. N Engl J Med 2016; 375(4): 311-322. doi:10.1056/NEJMoa1603827

19. Marso SP, Bain SC, Consoli A, Eliaschewitz FG, Jódar E, Leiter LA, et al: Semaglutide and cardiovascular outcomes in patients with type 2 diabetes. N Engl J Med 2016; 375: 1834-1844. doi:10.1056/NEJMoa1607141

\section{A szerzö levelezési címe:}

\section{Dr. Wittmann István}

Pécsi Tudományegyetem, Általános

Orvostudományi Kar, II. sz. Belgyógyászati Klinika és Nephrologiai Centrum,

7624 Pécs, Pacsirta u. 1.

E-mail: istvan.wittmann@aok.pte.hu 